\title{
Influence of Lifestyle and Cultural Values on Impulse Buying Behavior
}

\author{
Prof. Dr. Rizwan Raheem Ahmed \\ Department of Business Administration, Indus University, Gulshan-e-Iqbal, ST-2D, Block-17Karachi \\ Hassan Abbas Soomro, Kashif Ali, Wajid Ali \\ Faculty of Management Sciences, SZABIST, 90- Clifton, Block-5, Karachi
}

\begin{abstract}
The aim of research is to analyze the influence of life styles and cultural values on the impulse buying behavior of Pakistani university students and professionals in different organizations. For collection of data, survey technique was used from the students of different universities and organizations by adopting the convenient sampling technique. For analyzing the group differences between the variables of lifestyles and cultural values on impulse buying behavior, it was found that only gender role has the significant differences between male and female students and professionals on the impulse buying behavior. For analyzing the relationships among the variables of life style and cultural values, it was found that significant relationship exists among all the variables. The study also shows that variables of life style and cultural values such as, life satisfaction, security, financial satisfaction, gender role and in-group contact predict the influence on impulse buying behavior of the Pakistani students and professionals.
\end{abstract}

Keywords: Cultural values, Impulse buying behavior, Financial satisfaction

\section{INTRODUCTION}

\subsection{Impulse Buying}

Impulse buying describes as an unexpected purchase and considered as a quick decision making to get possession instantly (Rook \& Gardner, 1993; Rook, 1987; Rook \& Hoch, 1985). Impulse buying explains as less intentional, more tempting and most encouraging unlike planned purchasing behavior. In the case of high impulse, buyers are emotionally involved to the object and to wish instant satisfaction and they are likely to be an introspective in their thoughts (Hoch \& Loewenstein 1991; Thomson et al., 1990). The diminutive concentration pay by these consumers to the prospective negative consequences, that may perhaps outcome from their own actions (Hoch \& Loewenstein 1991; Rook 1987; O’ Guinn \& Faber, 1989).

Preceding studies accomplish in the United States and the Britain has exposed that there are lot of factors that influence to impulse buying behavior like the emotional condition or the moods of consumer (Donovan, Rossiter, Marcoolyn, \& Nesdale, 1994; Rook, 1987; Rook \& Gardner, 1993; Wein-berg \& Gottwald, 1982). There are many studies, which show the sentimental condition on the impulse buying behavior and also illustrate the result of consumer's moods. There are two types of moods positive and negative, which can affect the impulse buying. The consumers' positive mood is more favourable as compare to negative consumers' moods to the impulse buying (Rook and Gardner, 1993). According to Beatty \& Ferrell in 1998 also state that the positive moods of consumer showed more interest to purchase impulsively, whereas the impulse buyers were more excited as compared to non-buyers (Wein-berg and Gottwald's, 1982).

\subsection{Life Style}

Life style is an individual's living method in which they manage their physical, social, and psychosomatic and the economic environment on the basis of daily routine. Life style is combination of motivation, needs, inspirations and wants which influence through some factors just like family, cultures and social classes. The person's life style has ever a vital interest towards the marketers because they face every day different types people with different behaviours, feelings and attitudes. According to the life style marketing's point of view the people have distinguished themselves into different groups based on their common interests such as their work habits, spending their time and money into different activities.

In 1958 the idea lifestyle was firstly told by the researcher Bell, for the purpose of proper understanding of consumers' behavior (Rainwater, Coleman \& handel, 1959); Havinhurst \& Feigenbaum, 1959). The concept of lifestyle of Moor (1963) is the bridging point to understand this term in a better way. According to him the lifestyle is a decorative roadway of life in which people fit themselves (products, events and resources). It expresses that lifestyle and consumers' purchasing are inter linked. Lifestyle is very much important to divide the markets into segments keeping in view the target customers that are not possible by demographics only. Many researchers have studied the lifestyle of people to get proper information about it because demographics give incomplete information; therefore the marketers get hindrance in segmentation (Cooper, 1984). 


\subsection{Background of the Study}

Purchase decisions and buying behavior today are not that easy understand as these were a couple of centuries back, access to information and sophisticated tools to dig out the information even from the subconscious and unconscious of the customer has made it more complex than ever and adding fuel to the fire is the new field emerging as neuro-marketing, along with all these factors the recent improvement of self-conscience and economic status, impulse buying improved (Baumeister, 2002). It has changed the way people used to make decision rather we can say that it has been improved in a better way and Consequently, it is important to understand the variables which often figure out consumers' impulse buying (Solomon, 2009). Understanding these variables will help in knowing how the consumer is going to decide or what factors play role at front as in visible traits (Store outlook, packaging or the SKU etc.) and what are the factors that affect subconscious Acquiring impulsiveness is actually afflicted with different variables for instance particular, temporal, personal and economic and in addition simply by cultural variables (Tam \& Dholakia, 2011). These kinds of variables continue being very same in most circumstances if the customer is actually purchasing the very similar goods or perhaps unusual circumstances (Sharma, Sivakumaran \& Marshall, 2010). In addition to this other researchers ( Bellenger, Robertson, \& Hirschman, 1978), defined several variables which often have an effect on impulse buying, for instance external stimuli (store displays, buying rate of recurrence, special offers and also promotion, atmosphere of the super stores), demographic variables, internal perceptions and buying behavior and also Therefore, this study is going to find out how different lifestyles and different cultural values and beliefs influence on the buying behavior of the university students as how many of their decisions are impulse and how many are actually planned and what factors affect these decision.

To know the lifestyle and cultural values of the customers, every researcher is following the model of (Hofstede, 1993). According to him, there are five dimensions of cultural values such as, individualism/collectivism, uncertainty avoid-ness, masculinity and feminity, power distance. He also explained collectivism as community members or perhaps teams which often care for the other person and also attempt to help the members of the groups and individualism as how independent everyone is while making a decision and level of freedom a member has been provided by the members of the society of which he or she is a part of. According to Markus and Kitayama (1991), it has been observed that countries located in the eastern parts are more collectivistic and tend to live in communities and joint families while the developed nations such as western countries around the world have the individualistic lifestyle. Even though a research continues to be carried out simply by to evaluate the influence of life style cultural values on meaning of branded products, however there is no investigation to know the impact of cultural prices and also life-style in impulse buying behavior of Pakistani students. So that it become necessary to do an investigation about this subject matter. We tend to understand the degree of variety in the decision-making is a result of the way people live in Pakistan. This study will be beneficial for the marketers to understand the influence of lifestyle and cultural values on impulse buying behavior of university students because in Pakistan students are larger consumer of the products and they mostly focus on the unique lifestyles and along with this cultural values also have much importance in the buying behavior of the customers. And it will also help consumers understand the factors that marketers manipulate to make them make a purchase decision as their purchase decisions would be more conscious and more in their own control. This study will also add value in the academic literature for the researchers and practitioners as it is going to provide them sound knowledge about the future decision makers, as students today are going to have their own family or are going to support their family in the time period of a year or two approximately.

\subsection{Scope of the study}

Scope of the study is to understand the factors of life style and culture that affect the impulsive buying behavior of the students in Pakistan. We are trying to find the influence underlying factors have while a customer makes purchase decision which he or she did not plan or intend to at first but due to certain subconscious factors inclined the customer that he or she made an impulse decision. We are conducting this study as it is the growing phenomena of today that people often make purchases which they didn't intend to at first or products which they didn't need at all but due to some unknown reasons they made the decision. Usually this phenomena was more prevailing in the western society but as the world is submerging in a global village and we have become global citizens these difference are collapsing and we are similarly been affected and influenced by such dilemmas. We are going to study culture and lifestyles different aspects as to study culture and lifestyle and its impact we have selected these variables after going through many studies previously done on the topic and different theories that defined influencing variables of culture and life style.

\subsection{Cultural Variables}

- Group Influence

- Family Orientation 
- Gender Role

- Security

\subsection{Lifestyle Variables:}

- Satisfaction

- Lifestyle,

- Financial Satisfaction

\subsection{Objective of the study:}

We have divided the objective of our research into two parts:

- General objective

- Specific objective

\subsubsection{General objective:}

The purpose of this research is to study the level of impact these variables have on our purchase decision or buying behavior of university students and to check the relationship between them that either the way we live in the society and way we think and our values affect impulse behavior. The reason of conducting this study to find out the impact of difference in cultures has on buying behavior along with the effect of differencein the life style of students.

\subsubsection{Specific objective:}

- To examine influence of lifestyle and cultural values on impulse buying behavior of university students.

- To find out the correlation among the variables of lifestyle and cultural values of university students.

- To analyze the gender differentiation among the variables of lifestyle and cultural values of university students.

\subsection{Hypothesis}

To examine this issue, the followinghypothesis is suggested:

H1: Culture factors like (group influence, family orientation, gender role, and security) have an effect on impulse buying behavior.

H2: Lifestyle variables like (life satisfaction, lifestyle, and financial satisfaction) have an influence on impulse buying behavior.

H3: Lifestyle and Cultural variables have an influence on buying behavior of university students

H4: Lifestyle and cultural variables are positively correlated.

\subsection{Statement of Problem:}

There has been a lot of research conducted on the topic our study in the developed countries and marketers are utilizing it as an advantage for them in order to understand the behavior and decision making but no such informative study has been carried out in pakistan and thus we are conducting the research in pakistan as it is going to help both the marketeres and and consumers and it is going to set a base for futrthur studeis to be carried out. Our Basic research question is:

- $\quad$ Does culture and lifestyle affect impulse buying behavior?

By answering this Research question, it will be probable to find out whether or not culture has an important role while doing taking impulse buying decisions, and how does lifestyle affect our way of buying? This study will help us explore effects of these variables on impulse buying behavior.

\section{LITERATURE REVIEW}

Over the last many decades, it has been observed that consumer's patterns about the buying style have been changed ( Beatty \& Ferrell, 1998). The buyer that is viewed as realistic is thought to influence simply by a thing other than rationality (Kacen \& Lee, 2002). Buying behavior of the consumers is actually much more emotional as opposed to realistic (Stern, 1962). This investigation in addition discovered that you have various things that consequence buying that includes lifestyle and also cultural values while they push customers to the product/service that are easily affordable to them. Consumers apart from of lifestyle experience follow the a five steps while making a purchase decisions for instance need recognition, information about the products, evaluation of the alternatives products and services, and one of the important is purchase and post purchase decisions of the customers and it has also been observed that life style and cultural values have stronger influence in every step of the decision making stages (Pickett-Baker \& Ozaki, 2008). In relation to this a study done in the china has proved that collectivist culture of china has more influence on the purchasing patterns of the customers and while making a purchase the customers focus on those products that are beneficial for the group not for the individuals (Hawkins \& Mothersbaugh, 2009). A different investigator West (1951) discovered 
how the big difference is actually their own because of the customers life-style relating to the individualistic and also collectivist lifestyle from etic-level. The particular locating of the investigation ended up quite amazing it in fact mentioned that folks are most often much more delighted by their own lifestyle compared to individuals living in collectivist community, in financial terms satisfied and they also do much more traveling and the wonderful via collectivist lifestyle. Assael, H. (1985) discovered the impact of national lifestyle and cultural values on the buying behavior of the customers and found that national culture and life style has much importance in the people of the countries and they make their purchase decisions according to the national culture of the country (Ahmed et al., 2014).

A research carried out within Chinese superstore simply by Morgan and McCabe (2012) expressed those issues of store setting features impact on buyer buying behavior. Impulse buying can be an irregular method although they would it occurs regularly, from time to time it will become habit pertaining to customers to produce behavioral instinct purchases, and therefore, it is from time to time referred to as since habit of consumers that result in those to invest in impulsively.

An investigation ended up being carried out that unusual buying circumstances result in special buying behaviors resembling since whenever customers appreciate purchasing compared to they do much more impulse buying or perhaps should they have got time and effort compared to they do much more impulse buying (Young, 1989).

Markus (1991) characterized two disparate translation of once own a free sight (individualistic) \& a reliant sight(Marxist) \& the report indicated contrasts \& the demonstrated the European nation's individuals have a tendency to become distinctive west country's buyers choice decisions are entirely unexpected as compare to the world's different areas. These are the autonomous \& also they have a tendency in attempting innovative developments as compare to the individuals in communalist societies.

However still there will be numerous other elements that influence the drive purchasing conduct. The one other study conveyed through the Rosen and Howard (2000) demonstrates online arrangement to buy will be one kind of additional variable between that components facilitate individuals chose the drive buy \& the establish the motivation buys have the optimistic connection through the sum used to site. They have discovered that the effect to the store area in customers 'drive buy choice. He likewise closed that store's area is solitary kind of principle elements which impact the ton within drive choice.

The Baumeister in year (2002) studied a query, "what could be different explanations behind an individual to make a drive buy". The researcher establishes that motivation purchasing are the pleasurable. He has also establish that the buyers demonstrate optimistic reaction in that qualities of the vend surroundings also specifically or by implication. Numerous different inquires about were additionally directed that discovered customer way of life as one of the major component that influence drive purchasing choices.

Ahmed et al. (2014) concentrated on the impact of imprudent buyer style and unfortunate consuming. They found that Impulsive purchaser style assumes an essential part on shopper purchasing examples. Buyer hasty style as well as distinctive identity characteristics is likewise influencing drive purchasing choice.

\section{RESEARCH METHODOLOGY}

The goal of study is to find out the influence of customer life style and cultural values in impulse buying behavior. A questionnaire was developed for the collection of data from the students of different universities of Pakistan. A convenient sampling technique was used for the collection of data. For measuring the life style and cultural values, scale was adopted from the study of Sun, Horn, and Merritt (2004) and for measuring the impulse buying behavior scale was adopted form the study of (Rook, 1987). For the purpose of collecting the data from amongst many options researcher created an online survey form which was been circulated and been filled by 256 respondents. After screening the data from missing values, aberrant values and outliers only 251 cases were found useable for the study. All the proposed objectives were analyzed by using the SPSS 17.

\subsection{Research Design}

We have selected the Quantitative research design which will be followed in this research and the population of interest is limited to Karachi due to reasons of accessibility, convenience and low cost. Student samples are minimized because reliance on students has been criticized previously in management studies due to lack of reallife managerial experience (Bello et al, 2009). Thus the selection criteria of sample are mainly inclined towards the students and professionals those who are working in different organizations, their responses as consumers as how they make their impulse buying decisions (Ahmed et al., 2014).

\subsection{Population}

Since our research is limited to consumers (like students and professionals those who are working in different organizations) who make impulse buying decisions, so our interest group includes Students and working professionals with different demographics, gender and educational as well as income level. 


\subsection{Sample Size and Techniques}

The online questionnaire was been filled by 200 students and professionals working in different organizations to collect data through simple random sampling including students and working professionals who are working in different organizations but are from SZABIST, IQRA, Indus University and IoBM in order to have broader responses. Simple random sampling is done due to ready availability and expedited data collection as shortage of time being main constraint in our research.

\subsection{Instrument Development}

The responses have been collected through the online questionnaire containing structured question to measure the impact of culture and lifestyle on impulse buying behavior. Data collection and results that will show the impact of difference in culture and lifestyles effect on impulse buying behavior. Which lifestyle would affect impulse buying behavior and whether or not the size of family effects our impulse buying decisions along with the cultural factors playing their role while buying decisions are been taken.

\subsection{Data Analysis}

After the data have been collected, the next step in the research process was data analysis. The purpose of this analysis is to interpret and draw conclusions from the collected data. Since we have found the impact of culture and lifestyle on impulse buying so we have applied multiple regression analysis. We have used Pearson corelation and T-Test to analyze the positive and negative relation and whether culture and lifestyle are affecting impulse buying behavior or not respectively. To make analysis of data we used SPSS software in which we make analysis in to two parts where part one will lead descriptive statistics that has been used to "describe and summarize data and include measures of central tendency (average) and dispersion (the spread of data or how close each other is to the measure of central tendency)"

\section{RESULTS AND DISCUSSION}

Independent sample t- test method was applied to test the differences among the customer's cultural values and lifestyle as specified in table 1.

Table 1: Independent sample t-test

\begin{tabular}{lrrrrc}
\hline & \multicolumn{1}{c}{$F$} & \multicolumn{1}{c}{ Sig. } & \multicolumn{1}{c}{ T } & \multicolumn{1}{c}{ Sig.(2-tailed) } \\
\hline Life Satisfaction & 9.010 & .003 & 1.414 & 248 & .159 \\
Financial Satisfaction & .144 & .705 & .535 & 248 & .593 \\
Lifestyle & .186 & .667 & 1.647 & 248 & .101 \\
Group Influence & .356 & .551 & -.735 & 248 & .463 \\
Family Orientation & .552 & .458 & -.038 & 248 & .970 \\
Gender Roles & 6.104 & .014 & 4.815 & 248 & .000 \\
Security and Stability & .037 & .848 & -.451 & 248 & .653 \\
\hline
\end{tabular}

Significant at 0.05 level (two tailed).

According to the t-test table it shows us that the value of gender is .000 which is less than 0.05 so gender role variable is the only variable from all the variable of cultural and lifestyle where significant difference happen between male and female customers though making impulse buying decision and hence from our $\mathrm{H} 1$ only gender have an effect and $\mathrm{H} 2$ is rejected means not any lifestyle variable impact on impulse buying. Coley and Burgess (2003) studied that gender differences show a dynamic role in cognitive and impulse buying. They also define that Gender affects differently on buying decisions, because male and female have different psyche to do things, hence, they make decisions in different styles (Ahmad et al., 2014).

Table. 2: Reliability Statistics

\begin{tabular}{|c|c|}
\hline Cronbach's Alpha & N of Items \\
\hline .805 & 8 \\
\hline
\end{tabular}

Reliability shows us the consistency in the result whenever we are computing the items of research repeatedly. The Cronbach's alpha for our study is $80.50 \%$.

To test our H4 we used the correlation technique to check the relationship among the constructs of cultural values and life styles of university students as presented in table 2. 


\subsection{Correlation Analysis}

Table 3: Correlation

\begin{tabular}{|c|c|c|c|c|c|c|c|c|}
\hline \multicolumn{2}{|c|}{$\begin{array}{l}\text { Collectivist and } \\
\text { Individualist } \\
\text { Lifestyle/Values }\end{array}$} & $\begin{array}{l}\text { Life } \\
\text { Satisfaction }\end{array}$ & $\begin{array}{c}\text { Financial } \\
\text { satisfaction }\end{array}$ & $\begin{array}{l}\text { Life } \\
\text { Style }\end{array}$ & $\begin{array}{l}\text { Group } \\
\text { influence }\end{array}$ & $\begin{array}{l}\text { Family } \\
\text { orientation }\end{array}$ & $\begin{array}{l}\text { Gender } \\
\text { roles }\end{array}$ & Security \\
\hline $\begin{array}{l}\text { Life } \\
\text { satisfaction }\end{array}$ & $\begin{array}{l}\text { Pearson } \\
\text { Correlation }\end{array}$ & 1 & & & & & & \\
\hline $\begin{array}{l}\text { Financial } \\
\text { satisfaction }\end{array}$ & $\begin{array}{l}\text { Pearson } \\
\text { Correlation }\end{array}$ & $.339 * *$ & 1 & & & & & \\
\hline Lifestyle & $\begin{array}{l}\text { Pearson } \\
\text { Correlation }\end{array}$ & $.361 * *$ & $.496 * *$ & 1 & & & & \\
\hline $\begin{array}{l}\text { In -Group } \\
\text { influence }\end{array}$ & $\begin{array}{l}\text { Pearson } \\
\text { Correlation }\end{array}$ & $.375 * *$ & $.365 * *$ & $.380 * *$ & 1 & & & \\
\hline $\begin{array}{l}\text { Family } \\
\text { orientation }\end{array}$ & $\begin{array}{l}\text { Pearson } \\
\text { Correlation }\end{array}$ & $.443 * *$ & $.402 * *$ & $.355 * *$ & $.357 * *$ & 1 & & \\
\hline $\begin{array}{l}\text { Gender } \\
\text { roles }\end{array}$ & $\begin{array}{l}\text { Pearson } \\
\text { Correlation }\end{array}$ & $.332 * *$ & $.240 * *$ & $.185^{* *}$ & $.299 * *$ & $.367 * *$ & 1 & \\
\hline Security & $\begin{array}{l}\text { Pearson } \\
\text { Correlation }\end{array}$ & $.184 * *$ & $.278 * *$ & $.289 * *$ & $.330 * *$ & $.288 * *$ & $.269 * *$ & 1 \\
\hline
\end{tabular}

** Correlation is significant at 0.01 levels (two tailed).

A Pearson Correlation test is applied to analyze the link among the variables of cultural values and lifestyle, the results tell us that there is significant relationship between all the variables of cultural values and life styles and our H4 is accept. All variables are significant at the 0.01 level (2-tailed) as shown in table 2.

\subsection{Regression Analysis}

Table. 4: Model Summary

\begin{tabular}{|c|c|c|c|c|}
\hline Model & $\mathrm{R}$ & R Square & Adjusted R Square & Std. Error of the Estimate \\
\hline 1 & $.620^{\mathrm{a}}$ & .385 & .367 & .52849 \\
\hline
\end{tabular}

a. Predictors: (Constant), security, life satisfaction, gender, financial satisfaction, group, lifestyle, family

Our R Square vale is $\mathbf{. 3 8 5}$ and it is greater than $\mathbf{1 0 \%}$ that show that our model is good. Our $\mathbf{R}$ vale is $\mathbf{0 . 6 2}$ and it shows us that our H3 is accepted and there is good co-relation between buying variables with independent factors.

Table. 5: Standardized Coefficients

\begin{tabular}{|l|c|c|c|}
\hline \multicolumn{3}{|c|}{ Standardized coefficients } \\
\hline Constant & $\boldsymbol{B}$ & $\boldsymbol{T}$ & Sig. \\
\hline Life satisfaction & & 1.809 & .072 \\
\hline Family Orientation & .083 & 1.376 & .170 \\
\hline Financial satisfaction & .184 & 2.991 & .003 \\
\hline In Group contact & .202 & 3.284 & .001 \\
\hline Life Style & .094 & 1.571 & .050 \\
\hline Security & .121 & 1.972 & .012 \\
\hline Gender roles & .12 & 2.52 & .002 \\
\hline
\end{tabular}

The result shows that impulse buying behavior is predicted by life satisfaction, gender role and financial satisfaction. The results in tables 3 are telling the strength of life satisfaction $(\beta=0.083 ; P<0.05)$, gender roles $(\beta=0.212 ; P<0.05)$ and financial satisfaction $(\beta=0.202 ; P<0.001)$, and in predicting the impulse buying behavior among university students.

\section{CONCLUSION AND RECOMMENDATIONS}

\subsection{Conclusion}

The aim and purpose of research is to analyze the influence of life styles and cultural values on the impulse buying behavior of Pakistani university students and professionals from different professions and organizations. It is therefore concluded that only gender role has the significant differences between male and female students 
on the impulse buying behavior. Apart from gender role no other variable has significance as to have impact on impulse buying behavior. For analyzing the relationships among the variables of life style and cultural values, it was found that significant relationship exists among all the variables. These all variables are positively corelated. The study also shows that variables of life style and cultural values such as, life satisfaction, security, financial satisfaction, gender role and in-group contact predict the influence on impulse buying behavior of the Pakistani students. The research shows that impulse buying behavior is not affected significantly by other variables except the gender role differences that have been defined. We tested four hypotheses, H1: "Culture factors like (group influence, family orientation, gender role, and security) have an effect on impulse buying behavior." H2: "Lifestyle variables like (life satisfaction, lifestyle, and financial satisfaction) have an influence on impulse buying behavior." H3: "Lifestyle and Cultural variables have an influence on buying behavior of university students" H4: "Lifestyle and cultural variables are positively correlated." We conclude that culturally gender has the significant difference where as the other variables were not significantly different. Life style variables like (life satisfaction, lifestyle, and financial satisfaction) do not have significant influence. Cutural variables have significant influence amongst students as the results have shown. And as per the findings from the corelation table all the elements are positively co-related.

\subsection{Recommendations}

Pakistani markets have shown a huge amount of growth and promises a great potential as in the near future the growring middle class and with more urbanization and infra structure develeopement and advancement in the field of IT the consumers are ging to be more sophisticated and more demanding and in order to fulfill these demands producers needs to understand more than just needs and wants and with the convergance of cultures the collectivist society is now converting in to more of individulistic and micro families. Opportunities rising from urbanization and growing number of working woman and both the parents working have changed the market place dynamics. And Producers are facing a great dilemma as to how to cater to these unknown demands, and to answer these queries research is to be conducted on consumer lifestyle patterns their purchasing behaviour and other elements that are in sub conscious that even certain people themselves are not aware of therefore we recommend that this part of the research is to focused and more research is to be conducted in this regard. Furthur research will elaborate the understanding and will help make producers design SKUs and packages accordingly.

\section{REFERENCES}

Rook, D. W. and Gardner M. P. (1993), "In the Mood: Impulse Buyings' Affective Antecedents”, pp. 1-28 in Janeen Arnold-Costa and Russell W. Belk (Eds.), Research in Consumer Behavior, Vol. 6, Greenwich, CT: JAI press.

Rook, D. W. (1987), “The Buying Impulse”, Journal of Consumer Research, Vol.14, September, pp. 189-199.

Rook, D., \& Hoch, S. (1985). Consuming impulses. Advances in Consumer Research, 7(1), 23-27.

Hoch, S. J., \& Loewenstein, G. F. (1991). Time-inconsistent preferences and consumer self-control. Journal of Consumer Research, 17(4), 492-507. http://dx.doi.org/10.1086/208573

THOMPSON, M., ELLIS, R. \& WILDAVSKY, A. (1990) Cultural Theory (Oxford, West View).

O'Guinn, T. C., \& Faber, R. J. (1989). Compulsive buying: A phenomenological exploration. Journal of Consumer Research, Vol.16, No.2, pp. 147-157, ISSN 0093-5301

Donovan, R. J., Rossiter, J. R., Marcoolyn, G., \& Nesdale, A. (1994). Store atmosphere and purchasing behavior. Journal of retailing, 70(3), 283-294. http://dx.doi.org/10.1016/0022-4359(94)90037-X

Wein-burg, P., and Gottwald W. (1982), "Impulsive consumer buying as a result of emotions," Journal of Business Research, Vol. 10, pp. 43-57.

Rainwater, Lee, Richard P. Coleman, and Gerald Handel (1959), Workingman's Wife, New York: Oceana Publications.

Havighurst, Robert J. and K. Feigenbaum (1959), "Leisure and Life Style," American Sociologist, 64, 396-404.

Moore, David G. (1963), "Life Style in Mobile Suburbia," in Toward Scientific Marketing, ed. Stephen A. Greyser, Chicago, IL: American Marketing Association, 151-164.

Cooper, Michael (1984) “Can Celebrities Really Sell Products?” Marketing and Media Decisions, Vol.19, 6465.

Baumeister, R. F. (2002). Yielding to Temptation: Self-control failure, impulsive purchasing, and consumer behaviour. Journal of Consumer Research, 28(4), 670-676. http://dx.doi.org/10.1086/338209

Solomon, M.R. (2009). Consumer Behaviour. Buying, Having and Being (8th edition). Upper Saddle river, Prentice Hall, (Chapter 1, 8).

Tam, Leona and Utpal M. Dholakia (2011), "Delay and duration effects of time frames on personal savings estimates and behavior," Organizational Behavior and Human Decision Processes, 114(2), 142-152.

Sharma, P., Sivakumaran, B., \& Marshall, R. (2010). Impulse buying and Variety seeking: A trait-correlates perspective. Journal of Business Research, 63, 276-83. http://dx.doi.org/10.1016/j.jbusres.2009.03.013 
Bellenger, D., Robertson D. H., and Hirschman E. C. (1978), “Impulse Buying Varies by Product”, Journal of Advertising Research, Vol. 18, December, pp. 15-18.

Hofstede, G. J. (1993). Cultural constraints in management theories. In J. T. Wren (Ed.), The leader's companion (pp. 253-270). New York: Free Press.

Markus, H. R. \& Kitayama, S. (1991). Culture and the self: Implications for cognition, emotion, and motivation. Psychological Review. 98. 224-53.

Beatty, S. E. and Ferrell M. E. (1998), “Impulsive Buying: Modeling Its Precursors”, Journal of Retailing, Vol. 74 No. 2, pp. 169-191.

Kacen, J. J., \& Lee, J. A. (2002). The Influence of Culture on Consumer Impulsive Buying Behavior. Journal of Consumer Psychology, 12(2), 163-176. http://dx.doi.org/10.1207/S15327663JCP1202_08

Stern, H. (1962), “The Significance of Impulse Buying Today”, Journal of Marketing, Vol. 26, April, pp. 59-63.

Pickett-Baker, J., \& Ozaki, R. (2008). Pro-environmental products: Marketing influence on consumer purchase decision. Journal of Consumer Marketing, 25(6), 281-293.

Hawkins, D., \& Mothersbaugh, D. (2009). Consumer behaviour. Building Marketing Strategy (11th ed.). McGraw-Hill/Irwin, (Chapter 16).

West, J. C. (1951), "Results of Two Years of Study into Impulse Buying", Journal of Marketing, Vol. 15, January, pp. 362-363.

Morgan, Felicia and Deborah Brown McCabe (2012), "Learning Why We Buy: An Experiential Project for the Consumer Behavior Course," Journal of Marketing Education

Assael, H. (1985), Marketing Management: Strategy and Action, Belmont, CA: Kent, pp. 127-135.

Ahmed RR, Ahmad N, Parmar V, and Khoso I, (2014), "Role of Packaging and Labeling on Pakistani Consumers Purchase Decision”, European Scientific Journal, Vol. 10 (16): 464-473.

YOUNG, O. (1989), International Cooperation: Building Regimes for Natural Resource Management and the Environment (New York, Cornell University Press).

Rosen K.T., and Howard A.L. (2000), “E-retail: gold rush or fool's gold?”, California Management Review, Vol. 42, spring, pp. 72-100.

Ahmed, R. R., Parmar, V., Ahmed, M. A. (2014), "Impact of Product Packaging on Consumer's Buying Behavior," European Journal of Scientific Research, Vol. 122 (4), pp. 125-134.

Sun, T., M. Horn, D. Merritt, 2004. "Values and lifestyles of individualists and collectivists: a study on Chinese, Japanese, British and US consumers", Journal of Consumer Marketing, 21(5): 318-331.

Adepoju-Bello AA, Ojomolade OO, Ayoola GA and Coker HAB (2009). Quantitative analysis of some toxic metals in domestic water obtained from Lagos metropolis. The Nig. J. Pharm.;42(1): 57-60.

Coley, A., \& Burgess, B. (2003). Gender Differences in Cognitive and Affective Impulse Buying. Journal of Fashion Marketing \& Management, 7, 282-295.

Ahmad N, Ahmed RR, Jahangir A, Mujtaba G, Shamim H, Baig R, (2014), "Impacts of Guerrilla Advertising on Consumer Buying Behavior", Information and Knowledge Management, Vol. 4 (8): 45-52. 
The IISTE is a pioneer in the Open-Access hosting service and academic event management. The aim of the firm is Accelerating Global Knowledge Sharing.

More information about the firm can be found on the homepage:

http://www.iiste.org

\section{CALL FOR JOURNAL PAPERS}

There are more than 30 peer-reviewed academic journals hosted under the hosting platform.

Prospective authors of journals can find the submission instruction on the following page: http://www.iiste.org/journals/ All the journals articles are available online to the readers all over the world without financial, legal, or technical barriers other than those inseparable from gaining access to the internet itself. Paper version of the journals is also available upon request of readers and authors.

\section{MORE RESOURCES}

Book publication information: http://www.iiste.org/book/

Academic conference: http://www.iiste.org/conference/upcoming-conferences-call-for-paper/

\section{IISTE Knowledge Sharing Partners}

EBSCO, Index Copernicus, Ulrich's Periodicals Directory, JournalTOCS, PKP Open Archives Harvester, Bielefeld Academic Search Engine, Elektronische Zeitschriftenbibliothek EZB, Open J-Gate, OCLC WorldCat, Universe Digtial Library, NewJour, Google Scholar

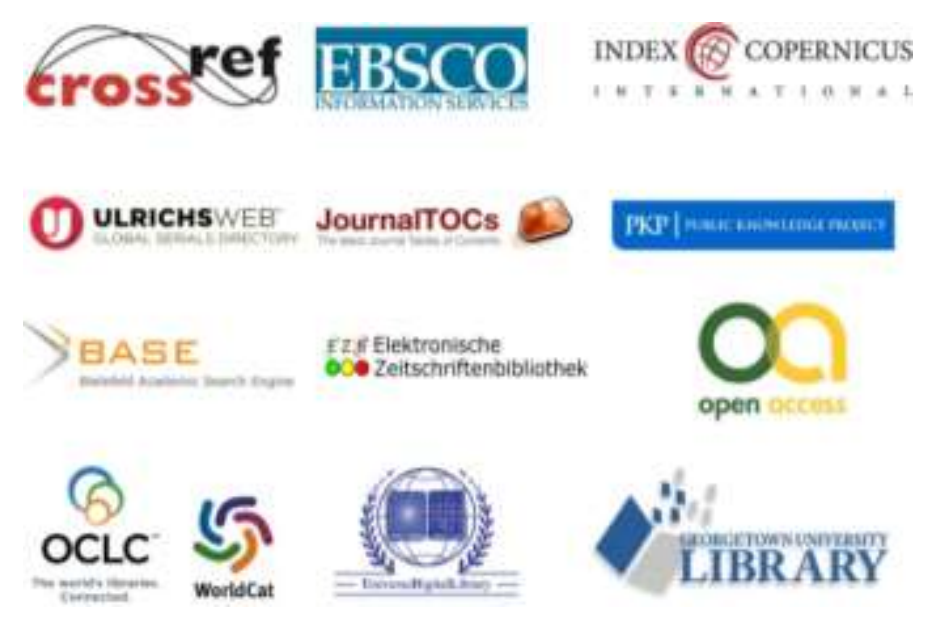

